\title{
THE CHARACTER AND MORAL VALUES IN "TO KILL A MOCKINGBIRD” BY HARPER LEE
}

\author{
Meity Dhaliani \\ English Language Education Programme, \\ Postgraduate Faculty, Universitas Indraprasta PGRI \\ e-mail: meity.dhaliani@gmail.com
}

\begin{abstract}
The purpose of the research is to find out the character and the moral values in the novel "To Kill a Mockingbird" by Harper Lee. This research is designed as qualitative research. The approach that the writer uses is qualitative. The data are collected by analyzing the data found in the novel. The analysis of the novel is undertaken on the dialogues. The result of the research is the form of character and moral values. 1) The character that emerges in the novel "To Kill a Mockingbird" is the protagonist, antagonist, and foil characters. The protagonist is $70 \%$, the antagonist is $18 \%$, and the foil character is $12 \%$. It means that the character who dominates in the novel is the protagonist. This novel's point is to lead the readers to appreciate others 2) There are seven moral values in the novel: respect, kindness, conscience, self-control, empathy, tolerance, and fairness. The moral value in the novel, respect gets $28 \%$, kindness is $10 \%$, conscience is $15 \%$, selfcontrol is $5 \%$, empathy is $15 \%$, tolerance is $13 \%$, and fairness is $15 \%$. It means that moral values that dominate in the novel convey particularly to the readers is respect.
\end{abstract}

Keywords: character; moral; value; moral values; novel

\section{Introduction}

Literature is an important subject to study as it reflects every aspect of human life, such as happiness, sadness, truth, justice, respect, courage, faith, and other pressing elements. It can serve as a guide for ourselves as well as for teaching others.

Literary work is one of the ways of sharing human thoughts that is actual events or fiction. It has a function in transmitting precious messages to the reader as a communication medium. It can keep everyone entertained and inspired. Literary work is a lovely type of job that can touch the reader's soul because literary works contain narratives that can dissolve readers' hearts in harmony with the emotions that protagonists experience in the story. Literature is generally divided into three components, Prose, Poetry, and Drama, respectively. The novel is one of the parts of prose. According to its length, the complexity of theme and development of characters, and plot, prose can be classified into a short story, novelette, and novel. Poetry is a piece of creative writing in verse that contains one expression of deep feeling or noble thought in beautiful language, written with communicating experience. While drama is the type of composition intended for performance on stage or in the theatre, some performers take on the characters' roles, execute the action stated, and engage in written dialogue. Hornby (1989:954) said that, in order to teach us, prose, poetry, and drama are not only entertainment but also a means to teach life philosophy. Little (1970: 1), who takes Matthew Arnold's statement in his book entitled "Culture and Anarchy," see literature as a principal element of its culture. It contains the record of people's value, their thoughts, problems, and conflicts as the reflection. Whether it is transmitted through the spoken or the written words, literature may reasonably be regarded as the chief art of humanity. Through this art, each generation tries to pass on to following "the best which has been thought and said." Therefore, literature can be one source or media for delivering the messages of morals and education to the reader. As has been explained in the statement, literature is a written message containing the author's experience, idea, or opinion. The author creates or describes characters in a literary work to express thoughts and emotions about things happening in the universe of stories. Characters in literary work have the authority to dominate the entire story. 
There are two types of characters, and they are main characters and supporting characters. The main character is a central figure or the focus of the story. Typically, the main character appears from the beginning to the end of the story. Even though the story and events never happened but as if they were happening through the description of the story. The stories written by the author in the form of short stories, novels, and romances, are usually taken from stories that exist around the life of the author. The writer would like to highlight the study through a novel in this research. As stated above, a novel is a literature type. A novel can be fiction. A fictional work has a deeper understanding, not just an author's imaginary story or wishful thinking, but a manifestation of the author's creativity in exploring and processing his mind's thoughts. In non-fiction, a story is about an actual search of authentic values that organize the whole words of complexity, which attempts to reflect and express something of the equality or value of human experience or conduct, as stated by Taylor (1981:24).

A novel is one of several literary works on language. Eagleton (1996:86) says that literary work reflects human thoughts and feelings supported by experience and observation. Literary works primarily through emotion and experience; literature students occupy the more precious feeling and experience. Therefore, a novel is a literary work that conveys many messages on the subject. A novel as a genre of literature provides a model containing life's significance. Values are strongly linked to humans in terms of human life-organizing ethics, beauty-related aesthetic areas, and the entry value by which humans understand religion and spiritual beliefs. In other words, a novel can be analyzed from the moral, in terms of the individual, social, and religious points of view. Usually, moral has a close relationship with the character, because moral is reflected by character. Therefore, a character also plays an essential role in the story. The people presented in a dramatic or narrative work are followed by particular moral, intellectual, and emotional qualities that seem from the dialogue and what they do. According to Bertens (2000:143147), value is something that interests us, something that we look for, something that pleases, something that is loved, and in short, value is something good. Value has a good connotation. Likewise, moral values are the message delivered by someone in a work of truth-values related to human glory. An author often inserts the moral value in their work to express his views on human life's valid values. Veugelers $(2008,1)$ says that moral values express ideas about the good life.

Moral values always uphold religious norms that have their distinct nature over other received doctrines. Moral values have their roots in revelation, unliked Geertz metaphysics, mainly linked to human reasons. In such a case, they are known as doctrines since they originate from the human mind's cognitive or rational nature.

In Alabama's deep Southern region, moral values are fostered and conveyed by the churches throughout the 1950s. Here in the South, Devine bosons remain premised on revelation for those with adherence to the churches, such as the black community. On the other hand, men have the more educated white community who uphold more on rationalism as a thought. Racism occurred rampantly during that particular time in America's southern state, as history shows that the black people were taught as barely human. In the American constitution, it was written that black people are only one-eighth human. It was also in the same place in Montgomery, Alabama, that Martin Luther King stage the civil rights speech for the black in 1965. These values come from religious advice, advice, regulations, and orders inherited through religion and culture on how people should live well to be truly good human beings. Through literature, the authors can set up the moral values that are patronizing so that the moral message can be captured well by the ones whose interest is in literature.

Good literature always invites readers to uphold norms and morals. Like other types of books, the novel is also used as a medium of education. The novel contains all of the significant figures with diverse events that come with an exciting plot. This is an excellent medium to convey the mission of education, culture, religion, and values of life such as morals, appreciation of honesty, the courage to face the trials of life, solidarity in friendship, or thoughts that a good person should own. From a fiction novel that sometimes takes you into the imaginative world, non-fiction unfolds the reality that you are getting to know real people and their lives. We may discover the message hidden so that not many individuals can feel it, but perhaps there is also a relatively straightforward or clear message that everyone can readily understand. It also provides expertise in a particular topic that helps. In the development of literary works, novels as a combination of knowledge and art are classified as literary works. Novels can reflect the culture of a nation and influence the culture itself. Aside from being a popular reading source, novels also become a medium for educating and providing information to the public - the novel functions as a historical process or 


\section{INFERENCE: Journal of English Language Teaching}

Vol. 3, No. 1, April - July 2020

p-ISSN: 2615-8671

e-ISSN: $2615-868 \mathrm{X}$

cultural process of a society presented in written form. The novel also functions as a medium of information, and the reader can see clearly what is happening in a particular society at a specific time.

Writing a novel is not easy and is not as quick as when we read it; it requires a very long time and process because it requires thought and a technical process, the thought process in the search for ideas and concepts. In comparison, the technical process of writing skills to turn ideas and concepts into a novel that is ready to read. A good novel leaves behind traces of reflection and careful research.

Harper Lee's "To Kill a Mockingbird" is a rare American novel that can be discovered in childhood with anticipation and read back to adulthood without fear of deceit. Few novels invoke the everyday experience of childhood so appealingly in a way that seems to persuade you are 17 or above fifty years old

The novel originated in Monroeville, Alabama's hometown of Lee - the small, southern town on which the fictional Maycomb is based. In addition to the Scottsboro Boys trials and another notorious case of interracial rape, her father's unsuccessful defense of a black man and his son accused of murder helped shape Lee's budding social consciousness and sense of a dramatic story. The town newspaper was published and edited by Lee's father, along with his legal practice. His consideration of the written word had as indeed an impact on Lee's sensitivity as his respect for the law. After Titus Pompon Fius Atticus, a Roman orator Cicero friend renowned as "a wise, learned and human man," Lee would name her idealized vision of her father. Lee called her work for a long time.

Set a Watchman, an early version of the novel, featured Scout as an adult returning to Maycomb. Tay Hohoff, the editor of Lee, asked her to rewrite the story from the perspective of a child she was doing. The manuscript for Go Set, a Watchman, was believed to have been lost until recently. Decades later, it was discovered and published in July 2015 by Harper Collins. Lippincott finally published To Kill a Mockingbird on July 11, 1960, when it had already been selected for its readers by an unprecedented four national mail-order book clubs. The Washington Post's first line echoed numerous similar comments praising the novel's moral impact: "A hundred pounds of sermons on tolerance, or an equal measure of invective lamenting its absence, will weigh far less on the scale of enlightenment than a mere 18 ounces of new fiction bearing the title "To Kill a Mockingbird."

This novel is about a small town in Alabama that is very accurate in depicting what life was like growing up in the south during the late 1930s, particularly in Alabama. The novel discusses the dark side of racism, bigotry, and what we call "white trash" now. Told through the vision of a child, the novel revolves around her father, who was a lawyer named Atticus Finch, who defended a hard-working, honest black man charged with raping a white woman, when in truth, the woman attempted to seduce him unsuccessfully. It sounds of squeaky screen door swing and front porch swing; haunted house and graveyard are things that the people who grew up in a tiny town in Alabama highly remember. Everyone knows everybody or at least somebody who does it. At a moment when distinct facilities for "colored individuals" were the standard that the hideous face of racism is told from a child's eyes, a young girl called Scout.

The novel is a masterpiece of storytelling, describing everything from being yelled at for walking on an old lady's grass to a father doing his best to explain empathy to a child who cannot understand why local farmers pay her father with vegetables grown instead of money. The novel tells other small sub-stories along the way about Boo Radley and his mysterious home and background, the fact that Atticus is a single parent, and that his children are raised, for the most part, as many of us were, by a black woman, who maintains the Finch household and is loved like family. In a history known as the Depression, the novel focuses on the moments, trials, and tribulations of life in a tiny southern town. Reading this novel provides us a view of living in the deep south (Alabama) afterward. The novel became a notable immediate success To Kill a Mockingbird. A year after the publication of the novel, 500,000 copies were sold and translated into ten languages.

The message of character and moral values is a message that contains both oral and written teachings about how humans live and act so that they become good human beings. The same goes for the novel that the writer is going to study. Based on the background above, the writer wants to research the title "Characters and Moral Values in "To Kill a Mockingbird" by Harper Lee." In this novel, there are moral values messages to be conveyed through the main characters. Then the following problem formulation can be made: 1) How is the character in "To Kill a Mockingbird" by Harper Lee?; 2) How is the Moral Value in "To Kill a Mockingbird" by Harper Lee? 


\section{Method}

A researcher must first decide what approach applies to the subject he will examine before doing a study. Good research will lead to a good assessment of accountability and credibility. Good research requires a good, effective and accountable process, and every researcher wants every work he or she has done to produce valid and accountable results.

The approach used by the writer in conducting this research is qualitative research. Creswell (2012:626) stated, "Qualitative research is an inquiry approach useful for exploring and understanding a central phenomenon. To learn about this phenomenon, the inquirer asks participants broad, general questions, collects the detailed views of participants in the form of words or images, and analyzes the information for description and themes. The researcher interprets the meaning of the information from this data, drawing on personal reflections and past research. The final structure of the final report is flexible, and it displays the researcher's biases and thoughts."

Based on the above argument, it can be seen that qualitative research is research carried out based on the phenomenon chosen by the researcher, being researched and, if possible, being represented in the form of words or statistics, and not explaining the quantitative analysis from the perception and personal reflections of the researcher. The description is flexible and displays the biases and thoughts of the researcher.

The qualitative approach is a type of approach to social science research that collects and works with non-numeric data and seeks to interpret these data's meaning to help us understand social life through the study of a specific research object. Noor (2011:34), as adapted from Denzin and Lincoln, stated that the qualitative approach is a process of research and understanding of researchers and subjects under study. This means that the research being carried out is a process and an understanding of the research subject in the researcher's study. Qualitative research is done naturally. It is mainly conducted to interpret phenomena in the field of study without any false data. Since this research aims to analyze Character and Moral Value in Harper Lee's novel To Kill a Mockingbird in light of the data analyzed, the writer uses descriptive qualitative research.

The description is flexible, and the key concept is that any idea or process studied in this kind of research is a central phenomenon and needs to be explored and understood. Overall, in qualitative research, the data will be processed by collecting, analyzing, and interpreting qualitatively in words or symbols. The method used in the study of "To Kill a Mockingbird" by Harper Lee is a descriptive qualitative. The type of research that the findings are not obtained through statistical procedures, definitive data, which is a value beyond the data that appears.

That is why a qualitative study does not emphasize generalizations but concentrates more on the meaning to express a variety of qualitative information with detailed and nuanced descriptions to describe the state of the phenomenon accurately. It is not restricted to data collection but instead includes the analysis ad interpretation. Descriptive assessment advised on the assessment is made solely based on the fact or phenomenon that empirically lives in its speakers (writer). This means that recorded and analyzed are elements in literary works as it is.

\section{Results and Discussion}

This chapter deals with the result and the discussion of the research. In this chapter, the writer will discuss the data related to the research object presented in the novel entitled "To Kill a Mockingbird." In this chapter, the writer attempts to answer the research problems in chapter one. After reading, understanding, and analyzing the novel, the writer would like to present the data's explanation and interpretation according to the novel's character and moral value in "To Kill a Mockingbird," written by Harper Lee. In this section, the writer would like to interpret the data she uses as a research object in the novel "To Kill a Mockingbird." The interpretation of data is divided into several parts:

\section{Character in the novel "To Kill a Mockingbird" by Harper Lee}

After analyzing the data found in the novel "To Kill a Mockingbird," the writer can conclude that the character which emerged in the novel "To Kill a Mockingbird," the Protagonist character is $70 \%$, Antagonist character is $18 \%$, and the Foil is $12 \%$.

Based on the character in the novel, the protagonist character shows the highest number, which is 70 $\%$. In this novel, the story is about Scout and Jem Finch growing up in the tired old Alabama town of 
Maycomb. Atticus is a local lawyer who strives to raise his children with honor and respect for their uniqueness as single parents. In reality, there is no money to be found anywhere in the city at that time, and things are challenging and stressful. The theme of a literary work is characterized by its core or prevailing ideas. The theories that seem to dominate the plot of To Kill a Mockingbird derive from the main characters' prejudices. The errors of judgment made by Jem and Scout, for example, help to establish dominant concepts of maturation and understanding. Atticus is trying to give his children a life lesson through the novel, respecting others and that all human beings, including their race, deserve respect. Antagonist characters only appear $18 \%$ of all dialogue that appears; this is the ideal number of percentages because it is far below the protagonists' percentage.

Foil characters show the lowest percentage, which is $12 \%$. Foil characters have some similarities within their background; however, they each have a different perception and behavior towards the same people. In this novel, Atticus Finch and Mr. Gilmer are clear examples of this because when compared side-by-side, one character always comes to the top at the end, which makes one character look superior to the other. Atticus and Mr. Gilmer are both highly educated; they went to law school and are both white; however, many of the major differences occur in Tom Robinson's trial. Mr. Gilmer is rude when questioning on trial, but Atticus always try to show respect to all. Atticus is standing up for Tom Robinson while Mr. Gilmer is trying to prove him guilty. Other characters show contradictive, but mostly they do not have any similarities.

\section{Moral Value in the novel "To Kill a Mockingbird" by Harper Lee}

After analyzing the data found in Harper Lee's novel "To Kill a Mockingbird," the writer will conclude that there is moral value in the novel "To Kill a Mockingbird," such as respect $28 \%$, kindness is $10 \%$, conscience is $15 \%$, self-control is $5 \%$, empathy is $15 \%$, and tolerance is $13 \%$. Furthermore, fairness is $13 \%$. According to Borba analyzed, after various moral values, respect shows the highest percentage among other moral values, which is $28 \%$. The novel would like to tell much about respect, which is something you receive by being a good person doing something great. All the people of Maycomb look up to Atticus and see him as a respectable person. Atticus is the most known character in the novel. He is a compassionate, loving father, the only Maycomb member who defends a black man, and he is always showing respect for others. Atticus is a great leader of his family, teaching values and life lessons to his children. He makes them better people by teaching them how to cope with the court and make fun of them. Atticus shows Scout how to respect others. Next, Scout begins to respect Atticus, respect "Boo" Radley, and eventually respect the whole race of Black people. He makes it a common practice to live his life as he wishes his children to live theirs, thus showing the qualities of an honest, respectable, and kind man. Throughout the trial process, Atticus teaches Jem and Scout that all human beings, including their race, deserve respect. "You do not understand a person until you crawl into his skin and walk around it." Ideally, the novel would also inspire the reader to appreciate others and to be willing to respect and apply them in their daily lives.

\section{Conclusions}

After the analysis has been carried out, the researcher concludes that the novel 'To Kill a Mockingbird by Harper Lee can be concluded that there are 32 data that have something to do with kinds of character and 39 data that have something to do with kinds of moral value. Besides, the study has two objectives. The first goal is to analyze the characters that the novel presents, and the second is to analyze the moral values that the novel tries to communicate to the reader.

There are three kinds of characters in the novel "To Kill a Mockingbird" by Harper Lee. They are the Protagonist character, the Antagonist character, and the Foil character. The protagonist is the most dominant character in the novel with a percentage of $70 \%$, the Antagonist is $18 \%$, and the Foil character is $12 \%$. The protagonist character gets the highest percentage because this novel, which Harper Lee writes, tries to send a message through the novel how to respect others and that all human beings, including their race, deserve respect. Foil characters show the lowest percentage, which is $12 \%$ of foil characters have some similarities within their background; however, they each have a different perception and behavior towards the same people. In this novel, Atticus Finch and Mr. Gilmer are clear examples of this because when compared side-by-side, one character always comes to the top at the end, which makes one character look superior to the other. Atticus and Mr. Gilmer are both highly educated; they went to law school and 
are both white; however, many of the major differences occur in Tom Robinson's trial. Mr. Gilmer is rude when questioning on trial, but Atticus always try to show respect to all. Atticus is standing up for Tom Robinson while Mr. Gilmer is trying to prove him guilty. Other characters show contradictive, but mostly they do not have many similarities.

There are seven moral values in the novel "To Kill a Mockingbird" by Harper Lee, they are: respect $28 \%$, kindness is $10 \%$, conscience is $15 \%$, self-control is $5 \%$, empathy is $15 \%$, tolerance is $13 \%$, and fairness is $13 \%$, Respect shows the top position with the highest percentage. There are around 11 dialogues that describe respect because the novel would like to tell much about respect, which is something you receive by being a good person or doing something great. All the people of Maycomb look up to Atticus and see him as a respectable person. Atticus is the most known character in the novel. He is a compassionate, loving father, the only Maycomb member who defends a black man, and he is always showing respect for others. Atticus is a great leader of his family, teaching values and life lessons to his children. He makes them better people by teaching them how to cope with the court and the people who are making fun of them. Atticus shows Scout how to respect others. Next, Scout begins to respect Atticus, respect "Boo" Radley, and eventually respect the whole race of Black people. He makes it a common practice to live his life as he wishes his children to live theirs, thus showing the qualities of an honest, respectable, and kind man. Throughout the trial process, Atticus teaches Jem and Scout that all human beings, including their race, deserve respect: "You do not understand a person until you crawl into his skin and walk around it." Ideally, the novel would also inspire the reader to appreciate others and to be willing to respect and apply them in their daily lives. In the novel, the moral values to kill a mockingbird are individual moral values, then social morals, and religious morals. Individual moral values often arise because this novel reflects the lives of brave, caring, and respectful human beings.

\section{References}

Abrams, M.H. (1999). A glossary of literary terms Seventh Edition. Massachusetts: Heinle and Heinle Ahmadi, A. (1991). Psikologi Sosial. Jakarta: Rineka Cipta.

Barcalow, E. (1994). Moral Philosophy Theory and Issues. California: Wordsworth.

Benne, A. N. R. (2004). An Introduction to literature, Criticism, and theory. London: Pearson Education Limited.

Bernard, K. (2001). Types of characters in fiction, Colin Welch's Education research. (online). https://www.academia.edu/29240479/Types of character in fiction.

Creswell, J. W. (2012). Educational Research: Planning, Conducting and Evaluating Quantitative and Qualitative Research. Pearson Education.

Creswell, J.W. (2013). Research Design Qualitative, Quantitative, Mixed Approaches. Thousand Oaks California: Sage Publication.

Culler, J. (2000). Literary Theory: A very short Introduction. Oxford: Oxford University Press.

George, I.N. \& Uyanga, U.D. (2014). Youth and Moral Values in changing society. IOSR Journal of humanities and social science, Vol. 19, Issue 6. page 40-44

Hurlock, E.B. (1990) Psikologi Perkembangan. Jakata Erlangga

Keller, S. (2007). The limits of loyalty. New York: Cambridge University Press.

Kenny, W. (1966). How to analyze fiction. New York: Monarch Press

Klarer, M. 2004. An Introduction to Literary Studies. London: Routledge.

Krippendorff, K. (2004). Content Analysis: An Introduction to methodology. ( ${ }^{\text {nd }}$ ed.) Thousand Oaks. California: Sage

Kountur, R. (2003). Metode Penelitian Untuk Penulisan Skripsi dan Tesis. Jakarta : PPM.

Lee, H. (1988). To Kill a Mockingbird. McIntosh and Otis, Inc. United State

Nurgiantoro, B. (2010). Teori Pengkajian Fiksi. Yogyakarta: Gajah Mada University

Robson, W.W. (2000). The definition of literature and other essays. Cambridge University Press.

Rokeach, M. (1979). Understanding human values and social. London: The Free Press

Sheng, C.I. (2008), A unitarian general theory of value. Amsterdam: Rodopi BV

Sugiyono. (2017). Metode Penelitian Kuantitatif, Kualitatif dan R\&D. Bandung: Pusat Bahasa Depdiknas.

Sumardjo, S. (2013). Apresiasi Sastra Indonesia. Jakarta: Erlangga

Sutopo, H.B. (2002). Metode Penelitian Kualitatif. Surakarta: UNS Press 
INFERENCE: Journal of English Language Teaching

Vol. 3, No. 1, April - July 2020

p-ISSN: 2615-8671

e-ISSN: 2615-868X

Venkataiah, N. \& Sandhya, N. (2002). Research in value education. New Delhi: APH Publishing Corporation

Zuriah, N. (2007). Pendidikan moral dan budi pekerti dalam perspektif perubahan. Jakarta Bumi Aksara 